\title{
Metabolic Characterization, Antioxidant Capacity, and In vitro Antiurolithiatic Potential of Achillea millefolium L.
}

\author{
Dolly Kain ${ }^{1}$, Suresh Kumar ${ }^{1, *}$, Vandana², Amrita Suryavanshi ${ }^{1}$, Atul Arya ${ }^{1}$ \\ 'Medicinal Plant Research Laboratory, Department of Botany, Ramjas College, University of Delhi, Delhi, INDIA. \\ 2Department of Chemistry, Dyal Singh College, University of Delhi, Delhi, INDIA.
}

\begin{abstract}
Objectives: The current study investigated the antioxidant and antiurolithiatic potential of $A$. millefolium along with its metabolic characterization. Methods: $A$. millefolium has been collected at vegetative (V) and mature (Inflorescence (I) and Stem and Leaves $(\mathrm{S}+\mathrm{L})$ ) stages and extracted in ethanol. Antioxidant potential has been determined by total phenolic content, total flavonoid content, ferric reducing antioxidant potential, total antioxidants through phosphomolybdate assay and free radical scavenging assays (1,1-diphenyl-2-picrylhydrazyl and 2,2'-azinobis(3-ethylbenzothiazoline-6-sulfonic acid). In vitro antiurolithiatic activity is determined by turbidity changes in artificial urine, nucleation assay, and aggregation assay. Fourier transform-infrared spectroscopy and gas chromatography-mass spectrometry has been used to characterize the active metabolites of plant $A$. millefolium. Results: Maximum antioxidant activity was observed in Inflorescence with values $76.58 \mathrm{mg}$ of GAE/g of extract, $18.82 \mathrm{mg}$ of RE/g of extract, $199.799 \mathrm{mg}$ of AAE/g of extract and $327.95 \mathrm{mg}$ of AAE/g of extract for TPC, TFC, FRAP and total antioxidants through phosphomolybdate assay respectively. Maximum radical scavenging activity was also observed in inflorescence with $86.3 \%$ and $69.655 \%$
\end{abstract}

inhibition against DPPH and ABTS free radicals at $1000 \mu \mathrm{g} / \mathrm{ml}$ concentration respectively. Maximum in vitro antiurolithiatic potential of plant $A$. millefolium observed in inflorescence i.e. $80 \%, 41.84 \%$ and $63.41 \%$ inhibition at $1000 \mu \mathrm{g} / \mathrm{ml}$ concentration for turbidity changes in artificial urine method, nucleation assay and aggregation assay respectively. FT- IR and GCMS of inflorescence of $A$. millefolium confirmed the presence of major functional groups and active metabolic compounds respectively. Conclusion: Inflorescence of plant $A$. millefolium is an excellent source of natural antioxidants with significant antiurolithiatic potential.

Key words: Achillea millefolium L., Antioxidant activity, Antiurolithiatic activity, Inflorescence, Active metabolites.

\section{Correspondence}

\section{Dr. Suresh Kumar,}

Associate Professor, Medicinal Plant Research Laboratory, Department of Botany, Ramjas College, University of Delhi, Delhi-110007, Delhi, INDIA

Email id: suresh.kumar@ramjas.du.ac.in

DOI: 10.5530/jyp.2021.13.44

\section{INTRODUCTION}

Free radicals are normally generated in the cell like during respiration and have some beneficial role to play in cell but become harmful when produced in excessive amount in response to external stress like UV irradiation, X-rays, gamma-rays, pollutants and any disease condition which leads to oxidative stress. This oxidative stress elicit on set of many diseases like cancer, cardiovascular diseases, asthma, diabetes, stroke, infertility and neurodegenerative diseases, kidney stones. Antioxidants are free radical scavengers and thus convert the oxidants into their less toxic forms and therefore play an important role in curing of various diseases which results in the production of ROS and cause damage to cell. Plants are excellent source of natural antioxidants and produce various secondary metabolites to boost their defense mechanisms. ${ }^{1}$ Urolithiasis is the process of formation of kidney stones in the urinary tract. Kidney stones are one of the most painful disorders of global concern. Super saturation of urine with stone forming substances or imbalance between promoters and inhibitors of kidney stones are two major cause of stone formation. Kidney stone formation i.e. urolithiasis occurs in three major steps including super saturation of urine, nucleation and aggregation. ${ }^{2}$ Kidney stones vary in composition like calcium oxalate, calcium phosphate, struvite (magnesium ammonium phosphate) and urate with calcium oxalate stones being the most prevailing. Treatment of kidney stones involves various types of clinical procedures including surgical treatment like extracorporeal shock wave lithotripsy (ESWL) and percutaneous nephrolithotomy (PNL) but different plants reported to have therapeutic potential for treatment of Urolithiasis. ${ }^{3,4}$ A. millefolium commonly known as yarrow is a high altitude plant mainly characterized by numerous white flowers arranged in corymbose cluster with flat headed appearance $^{5}$ and reported as diuretic, anti-inflammatory, antispasmodic, antibacterial, haemostatic, and hypertensive. ${ }^{6}$ Present study has been design to study the antioxidant and in vitro antiurolithiatic potential of plant $A$. millefolium with its metabolic composition.

\section{MATERIALS AND METHODS}

\section{Chemicals}

All chemicals (Folin-Ciocalteu reagent, gallic acid, ethanol, sodium nitrite solution, aluminum chloride, rutin, TPTZ solution, acetate buffer, ferric chloride solution, chemicals for phosphomolybdate reagent, ABTS $^{\bullet+}$, potassium persulfate, potassium phosphate buffer, chemicals for $\mathrm{AU}$, Tris, $\mathrm{NaCl}$, calcium chloride, sodium oxalate) used were of good quality and analytical grade. DPPH was procured from Sigma Aldrich.

\section{Collection, identification, and extraction of $A$. millefolium}

Plant A. millefolium was collected from Poonch District, Jammu and Kashmir at two different growth stages i.e. vegetative (V) and mature separated into stem + leaves $(\mathrm{S}+\mathrm{L})$ and inflorescence (I). For identification of plant herbarium specimens were submitted in the (RHMD) NISCAIR with reference ID's NISCAIR/RHMD/consult/2017/3084-33 and

This is an open access article distributed under the terms of the Creative Commons Attribution-NonCommercial-ShareAlike 4.0 License, which allows others to remix, tweak, and build upon the work non-commercially, as long as the author is credited and the new creations are licensed under the identical terms. 
NISCAIR/RHMD/consult/2018/3293-94. Extraction of plant samples was done by soxhlet method in ethanol.

\section{Total phenolic content}

Total phenolic content (TPC) of plant extract was determined according to the method of Slinkard et al. ${ }^{7}$ To $300 \mu \mathrm{l}$ of plant extract $(1 \mathrm{mg} / \mathrm{ml}), 1 \mathrm{ml}$ ethanol, $3.16 \mathrm{ml}$ distilled water and $200 \mu \mathrm{l}$ Folin-Ciocalteu reagent was added. $600 \mu \mathrm{l}$ of $10 \%$ sodium carbonate solution added after $8 \mathrm{~min}$ of incubation at RT, test tubes were wrapped using aluminum foil and incubated at $40^{\circ} \mathrm{C}$ for $30 \mathrm{~min}$ in water bath. For blank equal volume of ethanol was used instead of plant extract. The absorbance value was taken at $765 \mathrm{~nm}$ using UV visible spectrophotometer. The standard curve was obtained using gallic acid. TPC was determined in terms of mg of gallic acid equivalent (GAE) per g of extract.

\section{Total flavonoid content}

The total flavonoid content (TFC) was determined according to method of Ahmed et al. ${ }^{8}$ To $300 \mu \mathrm{l}$ extract $(1 \mathrm{mg} / \mathrm{ml}), 3.4 \mathrm{ml}$ aqueous ethanol (30\%), $150 \mu \mathrm{l}$ of $0.5 \mathrm{M}$ aq. sodium nitrite solution and $150 \mu \mathrm{l}$ of $0.3 \mathrm{M}$ aluminum chloride solution were added. After $5 \mathrm{~min}, 1 \mathrm{ml}$ of $1 \mathrm{M}$ sodium hydroxide solution was added, shaken well and absorbance was recorded at $506 \mathrm{~nm}$ using UV visible spectrophotometer. For blank equal volume of ethanol was used instead of plant extract. Standard curve was obtained using rutin and TFC was determined in terms of mg of rutin equivalent (RE) per g of extract.

\section{Ferric reducing antioxidant potential}

FRAP was determined according to the method of Benzie and Strain. ${ }^{9}$ For FRAP reagent $25 \mathrm{ml}$ acetate buffer ( $30 \mathrm{mM}$; pH 3.6), $2.5 \mathrm{ml}$ TPTZ solution (10 $\mathrm{mM}$ in $40 \mathrm{mM} \mathrm{HCl})$ and $2.5 \mathrm{ml}$ ferric chloride solution (20 $\mathrm{mM}$ ) were prepared, mixed and incubated for $15 \mathrm{~min}$ at $37^{\circ} \mathrm{C}$. Standard curve was obtained using Ascorbic acid (vitamin C). $2.85 \mathrm{ml}$ of FRAP reagent was taken in a test tube and $150 \mu$ of plant sample $(1 \mathrm{mg} / \mathrm{ml})$ or standard was added, and this mixture was incubated in the dark for $30 \mathrm{~min}$, and absorbance value was taken at $593 \mathrm{~nm}$. For blank equal volume of ethanol was used instead of plant sample. FRAP was determined in terms of mg of ascorbic acid equivalents (AAE) per g of extract.

\section{Phosphomolybdate assay for total antioxidant capacity}

Total antioxidant capacity of extracts was determined by phosphomolybdate assay proposed by Prieto et al. ${ }^{10}$ the procedure described by Jan et al. ${ }^{11}$ and Mashwami et al. ${ }^{12}$ with slight modification. To $300 \mu \mathrm{l}$ plant extract $(1 \mathrm{mg} / \mathrm{ml}), 3 \mathrm{ml}$ of phosphomolybdate reagent $(28 \mathrm{mM}$ sodium phosphate, $0.6 \mathrm{M}$ sulfuric acid, and $4 \mathrm{mM}$ ammonium molybdate) was added. Test tubes were wrapped using aluminum foil and were incubated for $90 \mathrm{~min}$ at $95^{\circ} \mathrm{C}$. Reaction mixture allowed to cool at room temperature and its absorbance were recorded at $765 \mathrm{~nm}$. Standard was obtained using ascorbic acid. For blank equal volume of ethanol is used instead of plant sample. TAC was determined in terms of mg of ascorbic acid equivalents (AAE) per $g$ of extract.

\section{1, 1-diphenyl-2-picrylhydrazyl radical scavenging assay}

The DPPH free radical scavenging assay was performed according to the method of Brand-Williams et al. ${ }^{13}$ with slight modification. Stock of DPPH radical was prepared by mixing $2.4 \mathrm{mg}$ DPPH in $10 \mathrm{ml}$ of ethanol and was stored in a refrigerator for further use. The working solution of the radical was obtained by diluting the stock with ethanol until an absorbance value of $0.98( \pm 0.02)$ at $517 \mathrm{~nm}$ was observed. ${ }^{14}$ To $3 \mathrm{ml}$ of DPPH working solution, $100 \mu$ plant extract $(100 \mu \mathrm{g} / \mathrm{ml}$ to $1 \mathrm{mg} / \mathrm{ml})$ was added and incubated for $30 \mathrm{~min}$ at RT in dark. Absorbance value was taken at $517 \mathrm{~nm}$.

\section{2, 2'-azino-bis-3-ethylbenzotiazolin-6-sulfonic acid radical scavenging assay}

$\mathrm{ABTS}^{\bullet+}$ decolorization assay was done by method of Re et al. ${ }^{15}$ The working solution of $\mathrm{ABTS}^{++}$radical having ABTS $(7 \mathrm{mM}, 9.5 \mathrm{ml})$ and potassium persulfate $(100 \mathrm{mM}, 245 \mu \mathrm{l})$, distilled water was added to raise the volume up to $10 \mathrm{ml}$. This solution was stored in dark at RT for $18 \mathrm{~h}$, and diluted with potassium phosphate buffer $(0.1 \mathrm{M}, \mathrm{pH} 7.4)$ to an absorbance of $0.70( \pm 0.02)$ at $734 \mathrm{~nm} .100 \mu \mathrm{l}$ of sample $(100-1000 \mu \mathrm{g} / \mathrm{ml})$ and $2.90 \mathrm{ml}$ of ABTS radical working solution were mixed thoroughly and absorbance value was taken at $734 \mathrm{~nm}$.

The percent DPPH/ABTS radical scavenging activity was calculated using the following formula:

$$
\% \text { Antioxidant activity }=\left[\left(A b s_{c}-A b s_{s}\right) / A b s\right] \times 100 .
$$

Where $\mathrm{Abs}_{\mathrm{c}}$ and $\mathrm{Abs}_{\mathrm{s}}$ are absorbance of control and sample respectively. For control $100 \mu \mathrm{l}$ of ethanol was added instead of sample and ascorbic acid (AA) was used as standard.

\section{Turbidity changes in artificial urine}

The artificial urine (AU) was prepared according to the method of Burns and Finlayson ${ }^{16}$ and had the following composition: sodium chloride $105.5 \mathrm{mmol} / \mathrm{l}$, sodium phosphate $32.3 \mathrm{mmol} / 1$, sodium citrate 3.21 $\mathrm{mmol} / \mathrm{l}$, magnesium sulfate $3.85 \mathrm{mmol} / 1$, sodium sulfate $16.95 \mathrm{mmol} / 1$, potassium chloride $63.7 \mathrm{mmol} / 1$, calcium chloride $4.5 \mathrm{mmol} / 1$, sodium oxalate $0.32 \mathrm{mmol} / 1$, ammonium hydroxide $17.9 \mathrm{mmol} / 1$, and ammonium chloride $0.0028 \mathrm{mmol} / 1$. The AU was prepared fresh each day and $\mathrm{pH}$ adjusted to 6.0 .

Study without inhibitor: A volume of $2 \mathrm{ml}$ of AU was transferred into the cell and $1 \mathrm{ml}$ of distilled water added to it and blank reading was taken $1 \mathrm{ml}$ of $0.01 \mathrm{M}$ sodium oxalate was added, to the previous volume, and the measurement is immediately taken for a period of $420 \mathrm{sec}^{17}$

Study with inhibitor: Extract was suspended in distilled water, filtered and used at a final concentration of 100, 250, 500, 750 and $1000 \mu \mathrm{g} / \mathrm{ml}$. A mixture of $2 \mathrm{ml}$ of AU and $1 \mathrm{ml}$ of plant extract solution is versed in the cell. A blank reading was taken and then volume of $1 \mathrm{ml}$ of $0.01 \mathrm{M}$ sodium oxalate was added and the measurement is immediately taken for a period of $420 \mathrm{sec}^{17}$

$$
\% \text { Inhibition }=\{(\text { Abs. Control }- \text { Abs. Sample }) / \text { Abs. Control }\}{ }^{\star} 100
$$

\section{Nucleation assay}

For nucleation assay method of Hennequin et al. ${ }^{18}$ was used with some minor modifications. Solutions of calcium chloride and sodium oxalate were prepared at a final concentration of $3 \mathrm{mmol} / \mathrm{L}$ and $0.5 \mathrm{mmol} / \mathrm{L}$, respectively, in a buffer containing Tris $0.05 \mathrm{~mol} / \mathrm{l}$ and $\mathrm{NaCl} 0.15 \mathrm{~mol} / \mathrm{l}$ at pH5.5. $1.9 \mathrm{ml}$ of calcium chloride solution was mixed with $200 \mu \mathrm{l}$ of the herb extract at different concentrations and incubated for 30 minat $37^{\circ} \mathrm{C}$ in water bath. Crystallization was started by adding $1.9 \mathrm{ml}$ of sodium oxalate solution. The OD of the solution was monitored at $620 \mathrm{~nm}$ for 420 s. \% Inhibition $=\{($ Abs. Control- Abs. Sample $) /$ Abs. Control $\}{ }^{\star} 100$.

\section{Aggregation assay}

The method used was similar to that described by Hess et al. ${ }^{19}$ with some minor modifications. 'Seed' $\mathrm{CaOx}$ monohydrate (COM) crystals were prepared by mixing calcium chloride and sodium oxalate at $50 \mathrm{mmol} / \mathrm{L}$. Both solutions were equilibrated to $60^{\circ} \mathrm{C}$ in hot water bath for $1 \mathrm{~h}$ and then cooled to $37^{\circ} \mathrm{C}$ overnight. The crystals were harvested by centrifugation and then evaporated at $37^{\circ} \mathrm{C}$. COM crystals were used at a final concentration of $0.8 \mathrm{mg} / \mathrm{ml}$, buffered with Tris $0.05 \mathrm{~mol} / \mathrm{l}$ and $\mathrm{NaCl}$ $0.15 \mathrm{~mol} / \mathrm{l}$ at $\mathrm{pH} 5.7 .1 \mathrm{ml}$ extract was taken in test tube to which $3 \mathrm{ml}$ $\mathrm{COM}$ crystal solution was added and incubated $37^{\circ} \mathrm{C}$ and reading were recorded at different time interval of $30,60,90$, and $120 \mathrm{~min}$. 
$\%$ Inhibition $=\{($ Slope Control-Slope Sample $) /$ Slope Control $\}{ }^{*} 100$

\section{Metabolic characterization of A. millefolium}

Fourier transform infrared (FT-IR) spectrum of inflorescence of plant A.millefolium was obtained using spectrometer (Shimadzu) in the range of 400-4,000 $\mathrm{cm}^{-1}$ and gas chromatoraphy- mass spectrometry was performed by using GCMS program GCMS_QP2010 Ultra with following working conditions: column oven temperature $60^{\circ} \mathrm{C}$, injection temperature $260^{\circ} \mathrm{C}$, injection mode split, flow control mode linear velocity, pressure $73.3 \mathrm{kPa}$, flame thermionic detector, ion sources temperature $230^{\circ} \mathrm{C}$ and carrier gas saver off.

\section{Statistical analysis}

Performed by calculating \pm SEM and strong regression $\left(\mathrm{r}^{2}\right)$ value using Microsoft excel 2007.

\section{RESULTS}

Plant A. millefolium showed maximum TPC, TFC, FRAP and total antioxidants through phosphomolybdate assay in inflorescence i.e. $76.58 \mathrm{mg}$ of GAE/g of extract, $18.82 \mathrm{mg}$ of RE/g of extract, $199.799 \mathrm{mg}$ of AAE/g of extract and $327.95 \mathrm{mg}$ of AAE/g of extract respectively followed by stem and leaves $(\mathrm{S}+\mathrm{L})$ and lowest activity in vegetative stage $(\mathrm{V})$ (Table 1$)$. Plant A. millefolium showed significant radical scavenging activity (DPPH and ABTS) with maximum \% activity in inflorescence (I) i.e. $86.3 \%$ and $69.655 \%$ at $1000 \mu \mathrm{g} / \mathrm{ml}$ concentration followed by stem and leaves $(\mathrm{S}+\mathrm{L})$ and lowest activity in vegetative stage $(\mathrm{V})$. Plant $A$. millefolium showed increasing activity with increasing concentration i.e. $100 \mu \mathrm{g} / \mathrm{ml}$ to $1000 \mu \mathrm{g} / \mathrm{ml}$ of A. millefolium (Table 2).

Plant A. millefolium showed excellent \% inhibition of formation of calcium oxalate crystals in artificial urine with maximum activity in inflorescence (I) followed by stem and leaves $(\mathrm{S}+\mathrm{L})$ and lowest activity in vegetative stage $(\mathrm{V})$ with $80 \%, 55 \%$ and $34 \%$ inhibition at $1000 \mu \mathrm{g} / \mathrm{ml}$ respectively (Figure 1 (A)). Plant A. millefolium showed significant \% inhibition against nucleation of calcium oxalate stones with maximum activity in inflorescence followed by stem and leaves $(\mathrm{S}+\mathrm{L})$ and lowest activity in vegetative stage (V) with $41.84 \%, 36.45 \%$ and $33.92 \%$ inhibition at $1000 \mu \mathrm{g} / \mathrm{ml}$ concentration respectively (Figure 1 (B)). Plant A. millefolium showed excellent activity against aggregation of nuclei with similar order i.e. maximum in inflorescence (I) followed by stem

\section{Table 1: TPC, TFC, FRAP and phosphomolybdate assay of}

\section{Achillea millefolium L.}

\begin{tabular}{|c|c|c|c|c|c|}
\hline $\begin{array}{l}\dot{0} \\
\text { vi }\end{array}$ & 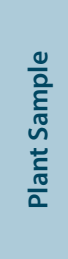 & 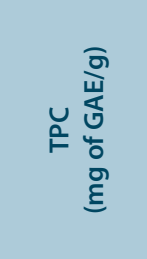 & 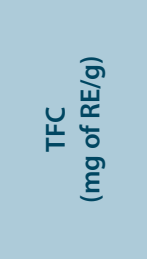 & 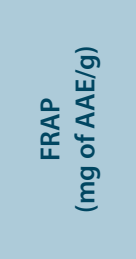 & 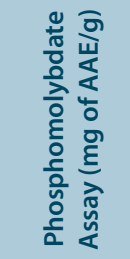 \\
\hline 1. & V & $5.08+0.05^{c}$ & $4.27+0.04^{c}$ & $\begin{array}{c}49.4977 \\
+0.25233^{c}\end{array}$ & $\begin{array}{c}85.29533+ \\
0.645297^{c}\end{array}$ \\
\hline 2. & $\mathrm{~S}+\mathrm{L}$ & $\begin{array}{c}32.21333 \\
+0.089505^{\mathrm{b}}\end{array}$ & $\begin{array}{c}6.17 \\
+0.111505^{\mathrm{b}}\end{array}$ & $\begin{array}{c}65.5993 \\
+0.91454^{\mathrm{b}}\end{array}$ & $\begin{array}{l}207.03+ \\
0.32078^{b}\end{array}$ \\
\hline 3. & I & $\begin{array}{c}76.57667 \\
+0.52667^{\mathrm{a}}\end{array}$ & $\begin{array}{c}18.82333 \\
+0.84667^{\mathrm{a}}\end{array}$ & $\begin{array}{c}199.799 \\
+4.48545^{\mathrm{a}}\end{array}$ & $\begin{array}{r}327.9467+ \\
0.534208^{\mathrm{a}}\end{array}$ \\
\hline
\end{tabular}

$\mathrm{V}=$ vegetative $A$. millefolium, $\mathrm{S}+\mathrm{L}=$ stem and leaves and $\mathrm{I}=$ inflorescence of mature A. millefolium, different superscript in increasing order of mean values denotes the statistically significant difference determined by one way ANOVA followed by $\mathrm{t}$ - test
Table 2: Radical scavenging activity (DPPH and ABTS) of Achillea millefolium L.

\begin{tabular}{|c|c|c|c|c|}
\hline \multirow{2}{*}{ 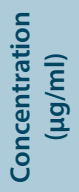 } & \multicolumn{4}{|c|}{$\%$ Inhibition + SEM (DPPH) } \\
\hline & AA & v & $S+L$ & I \\
\hline 100 & $57.86+0.16^{\mathrm{a}}$ & $33.76+0.24^{\mathrm{d}}$ & $36.235+0.235^{c}$ & $57.09+1.06^{\mathrm{b}}$ \\
\hline 250 & $90.385+0.015^{\mathrm{a}}$ & $38.39+0.21^{\mathrm{d}}$ & $41.51+0.49^{c}$ & $63.94+0.94^{\mathrm{b}}$ \\
\hline 500 & $92.73+0.47^{\mathrm{a}}$ & $39.735+0.035^{\mathrm{d}}$ & $53.06+0.34^{c}$ & $75.575+0.125^{b}$ \\
\hline 750 & $93.365+0.035^{\mathrm{a}}$ & $4034+0.34^{\mathrm{d}}$ & $63.615+0.015^{c}$ & $83.26+0.26^{\mathrm{b}}$ \\
\hline 1000 & $93.7+0.03^{\mathrm{a}}$ & $41.905+0.0475^{\mathrm{d}}$ & $70.475+1.2375^{c}$ & $86.3+0.00^{\mathrm{b}}$ \\
\hline \multicolumn{5}{|c|}{$\%$ Inhibition + SEM (ABTS) } \\
\hline 100 & $36.996+0.096^{\mathrm{a}}$ & $2.71+0.09^{d}$ & $12.095+0.095^{c}$ & $22.155+0.355^{\mathrm{b}}$ \\
\hline 250 & $78.67+2.33^{\mathrm{a}}$ & $5.4+0.4^{\mathrm{d}}$ & $16.12+0.18^{c}$ & $30.35+0.15^{b}$ \\
\hline 500 & $89.95+0.35^{\mathrm{a}}$ & $7.65+0.15^{\mathrm{d}}$ & $18.43+0.33^{c}$ & $60.39+0.39^{b}$ \\
\hline 750 & $90.74+0.06^{\mathrm{a}}$ & $10.155+0.155^{\mathrm{d}}$ & $30+0.2^{c}$ & $61.125+0.225^{b}$ \\
\hline 1000 & $91.19+0.1955^{a}$ & $28.555+0.255^{\mathrm{d}}$ & $34.025+0.075^{c}$ & $69.655+0.245^{\mathrm{b}}$ \\
\hline
\end{tabular}

$\mathrm{AA}=$ ascorbic acid, $\mathrm{V}=$ vegetative $\mathrm{A}$. millefolium, $\mathrm{S}+\mathrm{L}=$ stem and leaves and $\mathrm{I}$ = inflorescence of mature A. millefolium, different superscript in increasing order of mean values denotes the statistically significant difference determined by one way ANOVA followed by $\mathrm{t}$ - test

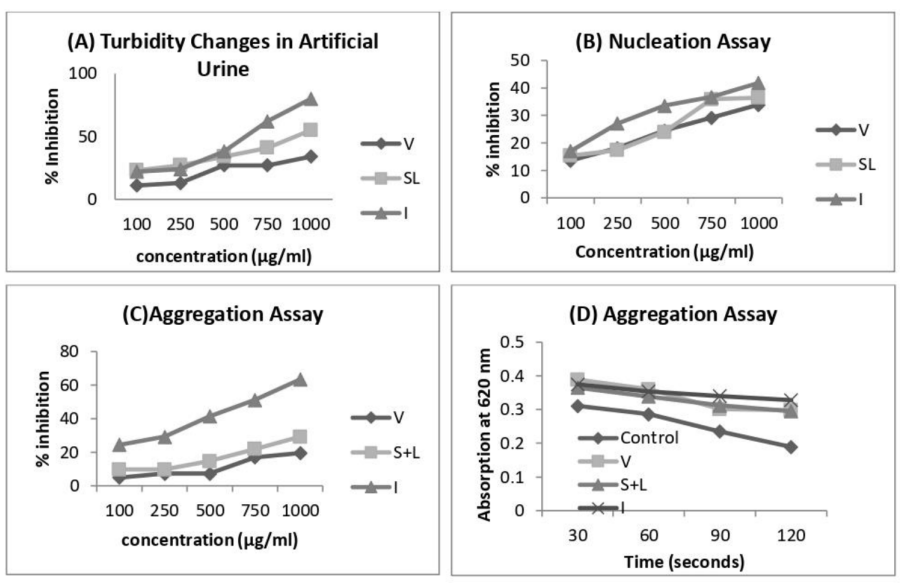

Figure 1: Represents Antiurolithiatic activity by Turbidity changes in Artificial Urine assay (A), Nucleation assay (B) and Aggregation assay (C and D) of plant A. millefolium ( $\mathrm{V}=$ vegetative plant, $\mathrm{S}+\mathrm{L}=$ stem and leaves, $\mathrm{I}=\mathrm{Inflorescence}$ ).

and leaves $(\mathrm{S}+\mathrm{L})$ and lowest activity in vegetative stage $(\mathrm{V})$ with $63.41 \%$, $29.26 \%$ and $19.51 \%$ inhibition at $1000 \mu \mathrm{g} / \mathrm{ml}$ concentration respectively (Figure $1(\mathrm{C})$ ). In aggregation assay absorption at $620 \mathrm{~nm}$ decreases with time due to aggregation of calcium oxalate nuclei as observed plant A. millefolium with maximum slope in inflorescence (Figure 1 (D)).

FT- IR and GC- MS has been used to study the metabolic composition of inflorescence (I) of A. millefolium in order to reveal the possible metabolites for its excellent antioxidant and in vitro antiurolithiatic activity. FT- IR of inflorescence of plant A. millefolium revealed the presence of major functional groups including $\mathrm{C}-\mathrm{Cl}, \mathrm{S}=\mathrm{O}, \mathrm{C}-\mathrm{H}, \mathrm{C}-\mathrm{N}$, $\mathrm{N}-\mathrm{O}, \mathrm{C}=\mathrm{C}, \mathrm{C}=\mathrm{O}, \mathrm{C}-\mathrm{H}$ and $\mathrm{N}-\mathrm{H}$ (Table 3 and Figure 2). GC- MS of inflorescence of plant A. millefolium revealed the presence of total 55 compounds with many compounds having different activities (Table 3 and Figure 3). 


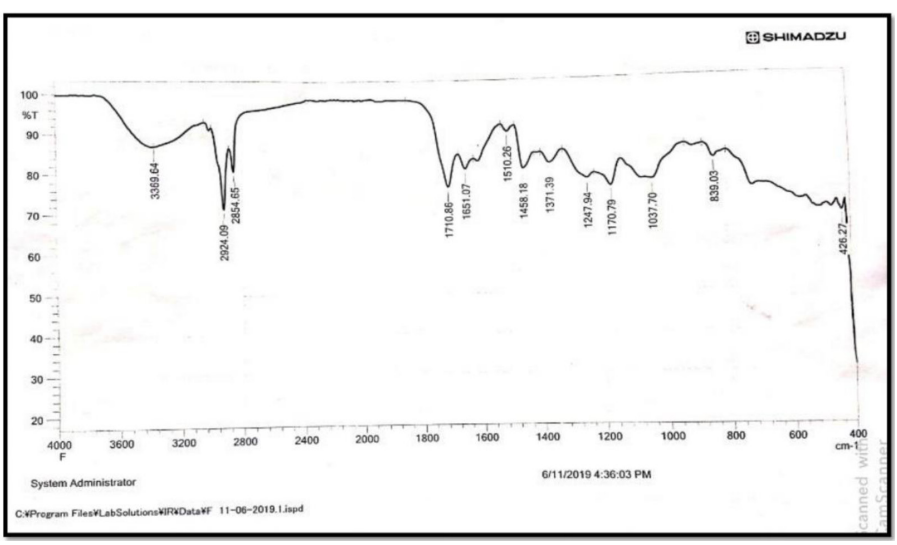

Figure 2: Represents FT- IR Graph of inflorescence of plant A. millefolium.

\section{DISCUSSION}

Farhadi et al. ${ }^{20}$ studied the TPC and TFC of A. millefolium at different growth stages with maximum activity in flowering stage. Georgieva et al. ${ }^{21}$ studied the total polyphenolic concentration of the water extracts of A. millefolium with $7.92 \pm 0.09 \mathrm{mg} \mathrm{GAE} / \mathrm{g} \mathrm{dw}$ comparable to current value of $6.12 \mathrm{mg} \mathrm{GAE} / \mathrm{g} \mathrm{dw}$ in ethanolic extract of inflorescence. Adam et al. ${ }^{22}$ have also reported total phenolic compounds of A. millefolium of leaf of water: acetonitrile (70: 30) extract with $0.645 \mathrm{mg}$ quercetin/g leaf which is much lower than the current value. Keser et al..$^{23}$ have studied water and ethanolic extract of flower, leaf and seed of A. millefolium and found maximum flavonoid content in water extract of leaves i.e. $0.979 \mathrm{mg} / \mathrm{ml}$ of rutin equivalent/ $\mathrm{g}$ of $\mathrm{dw}$ which is lower than the current value of $1.50 \mathrm{mg} \mathrm{QE} / \mathrm{g} \mathrm{dw}$ in ethanolic extract of inflorescence. Georgieva et $a .^{21}$ also studied FRAP activity of plant with maximum value $76.41 \pm 0.53 \mu \mathrm{M} \mathrm{TE} / \mathrm{g} \mathrm{dw}$. Plant A. millefolium showed maximum total

Table 3: FT- IR and GC- MS analysis of inflorescence of plant A. millefolium.

\begin{tabular}{|c|c|c|}
\hline \multicolumn{3}{|r|}{ FT- IR } \\
\hline Peak $\left(\mathrm{cm}^{-1}\right)$ & Stretching type & Functional Groups \\
\hline 839.03 & C-Cl stretching & halo compound \\
\hline 1037.70 & $\mathrm{~S}=\mathrm{O}$ stretching & Sulfoxide \\
\hline 1170.79 & C-H stretching & Alkane compound \\
\hline 1247.94 & C-N stretching & Amine \\
\hline 1510.26 & $\mathrm{~N}-\mathrm{O}$ stretching & Nitro compound \\
\hline 1651.07 & $\mathrm{C}=\mathrm{C}$ stretching & Alkene \\
\hline 1710.86 & $\mathrm{C}=\mathrm{O}$ stretching & aliphatic ketone, carboxylic acid, conjugated aldehyde \\
\hline 2854.65 & C-H stretching & Alkane \\
\hline 2924.09 & C-H stretching & Alkane \\
\hline 3369.64 & N-H Stretching & aliphatic primary amine \\
\hline \multicolumn{3}{|r|}{ GC-MS } \\
\hline S. No. & $\%$ Area & Compound name \\
\hline 1. & 0.80 & 2-methoxy-4-vinylphenol \\
\hline 2. & 0.46 & Phenol, 2,6-dimethoxy \\
\hline 3. & 0.62 & Cyclohexanemethanol, 4-ethenyl- $\alpha, \alpha, 4$ - trimethyl-3-(1- methylethenyl)-, [1R- $(1 \alpha, 3 \alpha, 4 \beta)]$ - \\
\hline 4. & 0.65 & 1H-cycloprop[e]azulen-7-ol, decahydro-1,1,7-trimethyl-4-methylene \\
\hline 5. & 0.30 & Guaiol \\
\hline 8. & 0.46 & 2-Naphthalenemethanol, 1,2,3,4,4a,5,6,7-octahydro-. alpha.,. alpha.,4a,8-tetramethyl-, (2R-cis)- \\
\hline 9. & 1.84 & .tau.-cadinol \\
\hline 10. & 7.22 & 2-Naphthalenemethanol, decahydro-. alpha.,. alpha., 4a-trimethyl-8-methylene-, [2R-(2. alpha.,4a. alpha.,8a. beta.)]- \\
\hline 11. & 0.54 & Tetradecanoic acid \\
\hline 12. & 13.78 & n-hexadecanoic acid \\
\hline 13. & 2.90 & Hexadecanoic acid, ethyl ester \\
\hline 14. & 0.44 & Androstan-17-one, 3-ethyl-3-hydroxy-, (5.alpha.)- \\
\hline 15. & 0.59 & 9,12-octadecadienoic acid (Z,Z)-, methyl ester \\
\hline 16. & 0.94 & Phytol \\
\hline 17. & 20.95 & 9, 12-octadecadienoic acid (Z,Z)- \\
\hline 18. & 8.10 & Linoleic acid ethyl ester \\
\hline 19. & 1.67 & Ethyl Oleate \\
\hline 20. & 0.61 & Santamarine \\
\hline 21. & 0.94 & Reynosin \\
\hline 22. & 0.28 & n-tetracosanol-1 \\
\hline 23. & 1.13 & Hexadecanoic acid, 2-hydroxy-1-(hydroxymethyl)ethyl ester \\
\hline 24. & 0.54 & Vitamin E \\
\hline 25. & 1.43 & Stigmasterol \\
\hline 26. & 3.22 & .gamma.-sitosterol \\
\hline 27. & 0.38 & alpha.-amyrin \\
\hline 28. & 0.56 & Lupeol \\
\hline
\end{tabular}




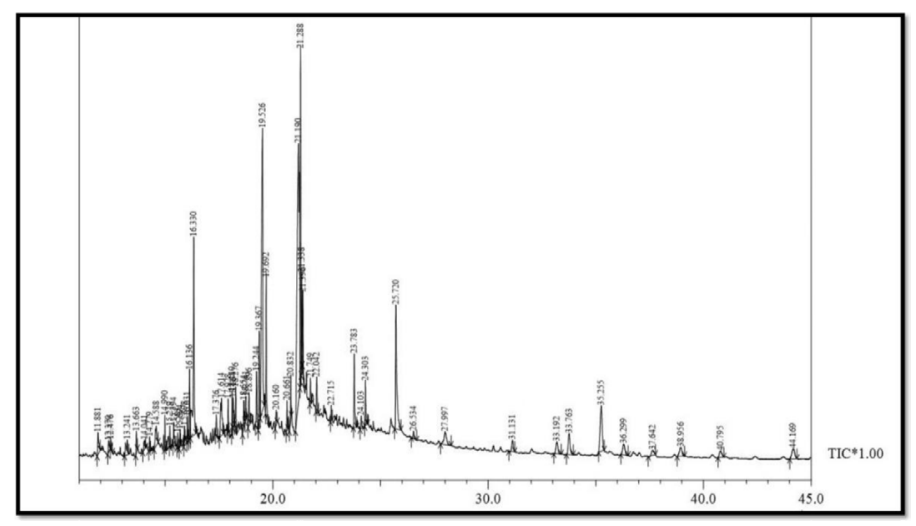

Figure 3: Represents GC- MS graph of inflorescence of plant A. millefolium.

antioxidants in inflorescence also by phosphomolybdate assay. Similar results have been obtained for radical scavenging activity of plant A. millefolium with maximum activity in inflorescence. Adam et al. ${ }^{22}$ found maximum DPPH radical scavenging activity of $18.31 \%$ in A. millefoium leaf extracted in water: acetonitrile (70:30). Keser et al. ${ }^{23}$ have found maximum ABTS radical scavenging activity in crude ethanolic extract of flower with $97.40 \%$ inhibition and maximum DPPH radical scavenging activity in the crude ethanolic extract of flower with $91.03 \%$ inhibition. Abdossi \& $\mathrm{Kazemi}^{24}$ also reported the DPPH activity in Achillea sp. Plant Achillea millefolium L. showed excellent antiurolithiatic potential against calcium oxalate kidney stones with significant $\%$ inhibition. Vamsi et al. ${ }^{25}$ have studied the antiurolithiatic potential of methanolic extract of Mucuna pruiens through turbidity changes in artificial urine method and reported maximum activity at $250 \mu \mathrm{g} / \mathrm{ml}$ concentration with $63.1 \%$ inhibition whereas Vennila et al. ${ }^{26}$ reported maximum activity at $100 \mathrm{mg} / \mathrm{ml}$ concentration with $98 \%$ inhibition in Melia dubia leaves. Similar assay has also been performed by Kumar et al. ${ }^{27}$ and Khare et al. ${ }^{28}$. Galani \& Panchal $^{29}$ reported the nucleation and aggregation activity of seeds of plant Centratherum anthelminticum with maximum $\%$ inhibition at $1000 \mu \mathrm{g} / \mathrm{ml}$ concentration i.e. $27.7 \%$ and $70.04 \%$ inhibition respectively. Similar assay of nucleation and aggregation has also been performed by Atmani \& $\mathrm{Khan}^{30}$ on Herniaria hirsuta, by Binu and Vijayakumari $^{31}$ on Strychnos potatorum and by Chandirika and Annadurai ${ }^{32}$ on Lantana camara.

FT- IR of inflorescence of A. millefolium revealed presence of major functional groups including halogen, alkane, alkene, alcohol, amine and nitro compounds (Table 3 ) which provide antibacterial, antioxidant activity and other pharmacokinetic properties to the compound or drug molecule as reported by Marc and Robinson ${ }^{33}$ and Pillai \& Nair $^{34}$. GC- MS revealed santamarine and reynosine which are principle identifying compounds of family asteraceae reported by Coronado-Aceves et al. ${ }^{35}$ GC- MS revealed many compounds reported to have antioxidant activity like 2-methoxy-4-vinylphenol, ${ }^{36}$ gamma.-sitosterol, ${ }^{37}$ tetradecanoic acid, ${ }^{38}$ stigmasterol, ${ }^{39}$ n-hexadecanoic acid, ${ }^{40}$ linoleic acid ethyl ester, hexadecanoic acid, 2-hydroxy-1-(hydroxymethyl)ethyl ester, ${ }^{41}$ alpha.amyrin, ${ }^{42}$ hexadecanoic acid, ethyl ester, vitamin $\mathrm{E},{ }^{43}$ phytol, ${ }^{44} \mathrm{n}$-tetracosanol- $1 .{ }^{45}$ Major antiurolithiatic compounds were also revealed including Lupeol, ${ }^{46}$ Stigmasterol, ${ }^{47}$ alpha. amyrin ${ }^{48}$ and gamma. sitosterol. ${ }^{49}$

\section{CONCLUSION}

A. millefolium showed increased antioxidant and in vitro antiurolithiatic activity from vegetative stage to mature stage and maximum activity was found in inflorescence. Hence, A. millefolium is an excellent source of natural antioxidants and have capacity to neutralize the damage cause by ROS generated in the cell during various diseased conditions including kidney stones formation. Inflorescence of plant A. millefolium showed excellent potential to be used as herbal drug to cure Urolithiasis.

\section{ACKNOWLEDGEMENT}

The authors are thankful to the Principal, Dr. Manoj K. Khanna, Ramjas College, Prof. SB. Babbar, Head, Prof. K.S. Rao and Prof. Veena Agrawal, Department of Botany, University of Delhi, Delhi for providing necessary facilities and encouragement during the course of investigation. The authors are acknowledging to the experts to review the manuscript for improvement.

\section{CONFLICT OF INTEREST}

The authors declare no conflicts of interest.

\section{REFERENCES}

1. Yadav A, Kumari R, Yadav A, Mishra JP, Srivatva S, Prabha S. Antioxidants and its functions in human body - a review Res. Environ. Life Sci. 2016;9(11):1328-31.

2. Ashok P, Koti BC, Vishwanathswamy AH. Antiurolithiatic and Antioxidant Activity of Mimusops elengi on ethylene glycol -Induced Urolithiasis in rats. Indian J Pharmacol. 2010;42(6):380-3. doi: 10.4103/0253-7613.71925, PMID 21189910.

3. Khaling M, Kumar S, Vandana. Current scenario of Urolithiasis and the use of medicinal plants as antiurolithiatic agents in Manipur (North East India): A Complete Review. Int J Herb Med. 2014;2(1):1-12.

4. Kain D, Kumar $S$, Suryavanshi $A$. Therapeutic values of medicinal plants against prevalence of Urolithiasis: a review. Med PInts Int Jrnl Phyt Rela Ind. 2018;10(4):268-77. doi: 10.5958/0975-6892.2018.00042.4.

5. Akram M. Minireview on Achillea millefolium Linn. J Membr Biol. 2013;246(9):661-3. doi: 10.1007/s00232-013-9588-x, PMID 23959026.

6. Bojor O. Guide of medicinal and aromatic plants from A to Z (in Romanian). Lux Romania: Fiat; 2003. p. 104.

7. Slinkard K, Singleton VL. Total phenol analysis: automation and comparison with manual methods. Am J Enol Vitic. 1977;28:49-55.

8. Ahmed D, Fatima K, Saeed R. Analysis of phenolic and flavonoid contents, and the anti-oxidative potential and lipid peroxidation inhibitory activity of methanolic extract of Carissa opaca roots and its fractions in different solvents. Antioxidants (Basel). 2014;3(4):671-83. doi: 10.3390/antiox3040671, PMID 26785233.

9. Benzie IFF, Strain JJ. Ferric reducing/antioxidant power assay: direct measure of total antioxidant activity of biological fluids and modified version for simultaneous measurement of total antioxidant power and ascorbic acid concentration. Methods Enzymol. 1999;299:15-27. doi: 10.1016/s0076-6879(99)99005-5, PMID 9916193.

10. Prieto P, Pineda M, Aguilar M. Spectrophotometric quantitation of antioxidant capacity through the formation of a phosphomolybdenum complex: specific application to the determination of vitamin E. Anal Biochem. 1999;269(2):337-41. doi: 10.1006/abio.1999.4019, PMID 10222007.

11. Jan S, Khan MR, Rashid U, Bokhari J. Assessment of antioxidant potential, total phenolics and flavonoids of different solvent fractions of Monotheca buxifolia fruit. Osong Public Health Res Perspect. 2013;4(5):246-54. doi: 10.1016/j.phrp.2013.09.003, PMID 24298440.

12. Mashwani Z, Khan MA, Irum S, Ahmad M. Antioxidant potential of root bark of Berberis lycium Royle. from Galliyat, Western Himalaya, Pakistan. Pak J Bot. 2013;45:231-4.

13. Brand-Williams W, Cuvelier ME, Berset C. Use of a free radical method to evaluate antioxidant activity. LWT Food Sci Technol. 1995;28(1):25-30. doi: 10.1016/S0023-6438(95)80008-5.

14. Zengin G, Aktumsek A, Guler GO, Cakmak YS, Yildiztugay E. Antioxidant properties of methanolic extract and fatty acid composition of Centaurea urvillei DC Subsp. hayekiana Wagenitz. Rec Nat Prod. 2011;5:123-32.

15. Re R, Pellegrini N, Proteggente A, Pannala A, Yang M, Rice-Evans C. Antioxidant activity applying an improved ABTS radical cation decolorization assay. Free Radic Biol Med. 1999;26(9-10):1231-7. doi: 10.1016/s0891-5849(98)00315-3, PMID 10381194

16. Burns JR, Finlayson B. A proposal for standard reference artificial urine in in vitro urolithiasis experiments. J Urol. 1980;18:167-9.

17. Bensatal A, Ouahrani MR. Inhibition of crystallization of calcium oxalate by the extraction of Tamarix gallica L. Urol Res. 2008;36(6):283-7. doi: 10.1007/s00240008-0157-1, PMID 19002446.

18. Hennequin C, Lalanne V, Daudon M, Lacour B, Drueke T. A new approach to studying inhibitors of calcium oxalate crystal growth. Urol Res. 1993;21(2):101-8. doi: 10.1007/BF01788827.

19. Hess B, Nakagawa Y, Coe FL. Inhibition of calcium oxalate monohydrate crystal aggregation by urine proteins. Am J Physiol. 1989;257(1 Pt 2):F99-106. doi: 10.1152/ajprenal.1989.257.1.F99, PMID 2750929. 
20. Farhadi N, Babaei K, Farsaraei S, Moghaddam M, Ghasemi Pirbalouti AG. Changes in essential oil compositions, total phenol, flavonoids and antioxidant capacity of Achillea millefolium at different growth stages. Ind Crops Prod. 2020;152. doi: 10.1016/j.indcrop.2020.112570, PMID 112570.

21. Georgieva L, Gadjalova A, Mihaylova D, Pavlov A. Achillea millefolium L. - phytochemical profile and in vitro antioxidant activity. Int Food Res J. 2015;22(4):1347-52.

22. 22. Adam M, Dobiás $P$, Eisner $A$, Ventura K. Extraction of antioxidants from plants using ultrasonic methods and their antioxidant capacity. J Sep Sci. 2009;32(2):288-94. doi: 10.1002/jssc.200800543, PMID 19072901.

23. Keser S, Celik S, Turkoglu S, Yilmaz O, Turkogl I. Determination of antioxidant capacities of ethanol and water extracts of Achillea millefolium L. (Yarrow). Asian J Chem. 2011;23:3172-6.

24. Abdossi V, Kazemi M. Bioactivities of Achillea millefolium essential oil and its main terpenes from Iran. Int J Food Prop. 2016;19(8):1798-808. doi: 10.1080/10942912.2015.1086787.

25. Vamsi S, Raviteja M, Kumar GS. In vitro antiurolithiatic potential of various extracts of Mucuna pruriens. IJPSR. 2014;5(9):3897-902

26. Vennila $V$, Marthal MA. In vitro analysis of phytochemical and antiurolithiatic activity of various extracts of Melia dubia leaves. World J Pharm Pharmaceu Sci.2015;4(4):1277-89.

27. Kumar GP, Arun M, Rishi K. Evaluation of Tinospora cordifolia for antiurolithiatic potential. J Pharm Biom Sci. 2011;9(14):1-5.

28. Khare P, Mishra VK, Arun K, Bais N, Singh R. Study on in vitro anti-lithiatic of Phyllanthus niruri L. leaves by homogenous precipitation and turbiditory method. Int J Pharm Pharm Sci. 2014;6(4):124-7.

29. J. Galani V. In vitro Evaluation of Centratherum anthelminticum Seeds for Antinephrolithiatic Activity. J Homeop Ayurv Med. 2014;03(1). doi: 10.4172/21671206.1000145

30. Atmani $F$, Khan SR. Effects of an extract from Herniaria hirsuta on calcium oxalate crystallization in vitro. BJU Int. 2000;85(6):621-5. doi: 10.1046/j.1464410x.2000.00485.x, PMID 10759652.

31. Binu TV, Vijayakumar B. In vitro antiurolithiatic activity of Strychnos potatorum L.f. South Indian. J Biol Sci. 2016;2(1):174-8.

32. Chandirika JU, Annadurai G. Inhibition of calcium oxalate crystallization in vitro by an extract of Lantana camara. Int. J Creative Res. Thoughts. 2018;6(1):1188-99.

33. Harrold MW, Zavod RM. Basic Concepts in Medicinal Chemistry. Drug Dev Ind Pharm. 2014;40(7):988-. doi: 10.3109/03639045.2013.789908.

34. Pillai LS, Nair BD. Functional group analysis of Cleome viscosa L. and C. burmanni W. \& A. (Cleomaceae) extracts by FT-IR. J Pharmacogn Phytochem. 2014;2(6):120-4

35. Coronado-Aceves EW, Velázquez C, Robles-Zepeda RE, Jiménez-Estrada $M$, Hernández-Martínez J, Gálvez-Ruiz JC, Garibay-Escobar A. Reynosin and santamarine: two sesquiterpene lactones from Ambrosia confertiflora with bactericidal activity against clinical strains of Mycobacterium tuberculosis. Pharm Biol. 2016;54(11):2623-8. doi: 10.3109/13880209.2016.1173067, PMID

\section{6.}

36. Ravikumar VR, Gopal V, SudhaT. Analysis of phytochemical constituents of stem bark extracts of Zanthoxylum Tetraspermum Wight \& Arn. Res J Pharm Biol Chem Sci. 2012;3(4):391-402.

37. Tripathi N, Kumar S, Singh R, Singh CJ, Singh P, Varshney VK. Isolation and Identification of $\gamma$ - Sitosterol by GC-MS from the Leaves of Girardinia heterophylla (Decne). Open Bioact Compd J. 2013;4(1):25-7. doi: 10.2174/ 1874847301004010025

38. Selvan PS, Velavan S. Analysis of bioactive compounds in methanol extract of Cissus vitiginea leaf using GC-MS. Rasayan J Chem. 2015;8(4):443-7.

39. Singariya P, Mourya KK, Kumar P. Gas chromatography-mass spectrometric analysis of acetone extract of Cenchrus ciliaris (Dhaman grass). Int J Sci Natl. 2015;6(4):652-61.

40. Abubakar MN, Majinda RRT. GC-MS Analysis and Preliminary antimicrobial activity of Albizia adianthifolia (Schumach) and Pterocarpus angolensis (DC). Medicines (Basel). 2016;3(1). doi: 10.3390/medicines3010003, PMID 28930113

41. Tyagi T, Agarwal M. Phytochemical screening and GC-MS analysis of bioactive constituents in the ethanolic extract of Pistia stratiotes L. and Eichhornia crassipes (Mart.) Solms. J Pharmacogn Phytochem. 2017;6(1):195-206.

42. Vashisht S, Singh MP, Chawla V. GC-MS analysis of phytocomponents in the various extracts of Shorea robusta Gaertn. F. Int J Pharmacogn Phytochem Res. 2017;9(6):783-8.

43. Kalita BC, Gupta DD, Das AK, Hui PK, Tag H. Gas chromatography - mass spectrometry of methanol extract of Urtica dioica L. from Arunachal Pradesh. India J Clin Tri Cas Rep. 2018;1(1):111.

44. Godara P, Dulara BK, Barwer N, Chaudhary NS. Comparative GC-MS analysis of bioactive phytochemicals from different plant parts and callus of Leptadenia reticulata Wight and Arn. Pharmacogn J. 2019;11(1):129-40. doi: 10.5530/ pj.2019.1.22.

45. Anand R, Patnaik GK, Kulshreshtha DK, Dhawan BN. Antiurolithiatic activity of lupeol, the active constituent isolated from Crateva nurvala. Phytother Res. 1994;8(7):417-21. doi: 10.1002/ptr.2650080708.

46. Manjula K, Rajendran K, Eevera T, Kumaran S. Effect of Costus igneus stem extract on calcium oxalate Urolithiasis in albino rats. Urol Res. 2012;40(5):499-510. doi: 10.1007/s00240-012-0462-6, PMID 22298189.

47. Dinnimath BA, Jalalpure SS, Patil UK. Antiurolithiatic activity of natural constituents isolated from Aerva lanata. J Ayur. Integr Med. 2017;8(1):226-32.

48. Devkar RA, Chaudhary S, Adepu S, Xavier SK, Chandrashekar KS, Setty MM. Evaluation of antiurolithiatic and antioxidant potential of Lepidagathis prostrata: A Pashanbhed plant. Pharm Biol. 2016;54(7):1237-45. doi: 10.3109/13880209.2015.1066397, PMID 26171886.

Article History: Received: 26-03-21; Revised: 02-05-21; Accepted: 05-06-21.

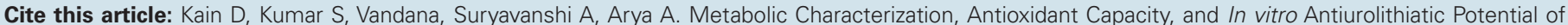
Achillea millefolium L. J Young Pharm. 2021;13(3):211-6. 